\title{
Body Length Composition and Recruitment Time of Hime Salmon Oncorhynchus nerka in Lake Chuzenji Judged by Experimental Fishing
}

\author{
Kiyoshi Yoshihara, ${ }^{* 1}$ Naoto Okumoto, ${ }^{* 2}$ Toshio Shikama, ${ }^{* 2}$ \\ Saburo Oda, ${ }^{* 2}$ Hisao Ishijima, ${ }^{* 3}$ Takayuki Shibuya, ${ }^{* 3}$ \\ Kimiyuki Kamiyama, ${ }^{* 4}$ and Hideo Soeda*1 \\ (Received November 14, 1990)
}

\begin{abstract}
Seasonal changes in the body length composition of hime salmon and its recrutitment time as fishing resources in Lake Chuzenji were examined on the basis of results of experimental fishing performed 13 times every odd month from March in 1985 to March in 1987. Throughout the whole examination periods, from January to May, a mode of body length was recognized in $25 \mathrm{~cm}$ to $26 \mathrm{~cm}$ mainly, although small number of smaller or larger fishes were caught up. However, the frequency of the appearance of small fishes started to increase in July and the mode was shifted to 18 to $19 \mathrm{~cm}$. In November, large-sized fishes with the body length of $28 \mathrm{~cm}$ or more ascended a stream for spawning and disappeared from the lake or were remained in a small number. It can be assumed that the recruitment into the fishing ground as fishing resources starts mostly in May when fishes grow into certain size with the main group having 18 to $19 \mathrm{~cm}$ of body length, thus filling the space left after the ascending.
\end{abstract}

Hime salmon Oncorhynchus nerka, a landlocked sockeye salmon, inhabits lake in North American continent, mainly Alaska and Canada, and Pacific countries of Northeast Asia., ${ }^{12}$ ) The original habitat of hime salmon in Japan is considered to be Lake Akan and Lake Chimikepp in Hokkaido, but it is now distributed widely in many lakes including Lake Shikotsu, Lake Towada and Lake Chuzenji. ${ }^{3-\text { s) }}$

Production of hime salmon in Lake Chuzenji has started in 1906 when 400 thousand fishes were transplanted from Lake Shikotsu and stocked.4) Thereafter, its transplantation and projects for artificial fertilization and stocking have been performed positively, thus resulting in the present basis of the hime salmon business in which the fish occupies important parts as the source of seedling supply and as a fishing target for local fishermen and general leisure fishing.

Though natural reproduction has been observed sometimes, most of the hime salmon resources in Lake Chuzenji have been supported by artificial fertilization and stocking of juveniles; 900 thousand juveniles at highest with mean numbers of 400 thousand from 1965 to 1978 , on the level of one million in 1984.") Thereafter, the number of stocked juveniles has started to decrease; 730 thousand in 1985, 970 thousand in 1986 and 350 thousand in 1987.

Under the present situation of increasing demands for hime salmon as a target fish for local fishermen and as tourism resources, it is necessary to establish a management system for the maintenance of resources, including determination of optimum numbers to be stocked, in order to accomplish permanent preservation of resources. However, in spite of the history of over 80 years on the transplantation, artificial fertilization and stocking business, it cannot be said that biological characteristics of this species in terms of natural resources and its movement in the lake are fully understood.

In this paper, we described the recruitment time of hime salmon as fishing resources from

*1 Department of Fisheries, College of Agriculture and Veterinary Medicine, Nihon University, Shimouma,

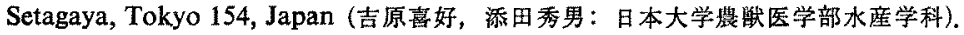

*2 Nikko Branch of National Research Institute of Aquaculture, Fisheries Agency, Chuguuji, Nikko 32116, Japan (奥本直人，鹿間俊夫，織田三郎：渼殖研究所日光支所).

*3 Tochigi Prefectural Fisheries Experimental Station, Yanadacho, Utsunomiya 321-31, Japan（石島久男， 浩谷隆之: 症木県水应試験場).

*4 Lake Chuzenji Fisheries Co-operative Association, Chuguuji, Nikko 321-16, Japan（神山公行：中神寺 湖漁業協同組合)。 
seasonal changes in body length composition, based on the results of experimental fishing in Lake Chuzenji.

\section{Methods}

Investigation Period and Fishermen Employed Experimental fishing was repeated 13 thimes during two years from March 1985 to March 1987, with each fishing being performed for two days in latter part of every odd month, excluding the examination in November 1985, when only day was available because of stormy weather.

A total of 23 fishermen were extracted at random from 160 members belonging to Lake Chuzenji Fisheries Co-operative Association. Age and fishing career (as of July 1985) of each fisherman thus extracted are shown in Table 1. Their mean career was 28.5 years. Because they have been experiencing fishing at the same area as professional for over 20 years on average, it may safely be said that there are no remarkable differences in technical skills between the extracted fishermen.
Fishing Plots

Lake Chuzenji is an oligotrophic lake located in Nikko City, northwestern part Tochigi prefecture, and the surface of the lake is 1271 meters above the sea level, with its area, maximum depth and mean depth are $11.3 \mathrm{~km}^{2}, 172 \mathrm{~m}$ and $94.6 \mathrm{~m}$, respectively..$^{\text {s) }}$

The lake was divided into 14 fishing plots as shown in Fig. 1, each plot was posted with one fisherman principle and the examination was performed by making uniform round of the plots. Each of the fishing plots 1 to 8 is prohibited area of fishing throughout the year and the other plots are open to the public for about 5 months from late in April to mid-September. The examination at the prohibition and during the closed season was performed by obtaining a special permission for fishing.

Fishermen were stationed at some fishing plots at random in every odd time and the examination was performed by means of a troll fishing generally called "Himetoro" for about 3 hours starting at just before sunrise of each examination day.

All individuals thus fished were examined for

Table 1. Age and fishing career of extracted fishermen as of July 1985

\begin{tabular}{cccccc}
\hline $\begin{array}{c}\text { Code of } \\
\text { fishermen }\end{array}$ & Age & $\begin{array}{c}\text { Starting year } \\
\text { of angler }\end{array}$ & $\begin{array}{c}\text { Entered year to } \\
\text { a member of Co-op }\end{array}$ & $\begin{array}{c}\text { Career in } \\
\text { angler (Year) }\end{array}$ \\
\hline 1 & A & 55 & 1949 & 1959 & 36 \\
2 & B & 57 & 1965 & 1965 & 20 \\
3 & C & 49 & 1955 & 1965 & 30 \\
4 & D & 45 & 1950 & 1958 & 35 \\
5 & E & 35 & 1979 & 1970 & 30 \\
6 & F & 36 & 1979 & 1981 & 6 \\
7 & G & 45 & 1950 & 1960 & 35 \\
8 & H & 60 & 1945 & 1955 & 40 \\
9 & I & 50 & 1945 & 1945 & 26 \\
10 & J & 60 & 1959 & 1959 & 20 \\
11 & K & 29 & 1965 & 1983 & 29 \\
12 & L & 50 & 1956 & 1960 & 28 \\
13 & M & 38 & 1960 & 1973 & 27 \\
14 & N & 38 & 1958 & 1972 & 35 \\
15 & O & 65 & 1950 & 1950 & 23 \\
16 & P & 36 & 1962 & 1977 & 26 \\
17 & Q & 43 & 1959 & 1975 & 30 \\
18 & R & 40 & 1955 & 1980 & 4 \\
18 & S & 49 & 1945 & 1960 & 43 \\
20 & T & 45 & 1976 & 1976 & 34 \\
21 & U & 63 & 1942 & 1942 & \\
22 & V & 67 & 1951 & 1965 & \\
23 & W & Others & & & 26 \\
\hline
\end{tabular}

Others: The staff of Co-operative Association, Fisheries Experimental Station and Nikko Branch of National Reserch Institute of Aquaculture.

Co-op.: Chuzenjiko Fisheries Comoperative Association. 

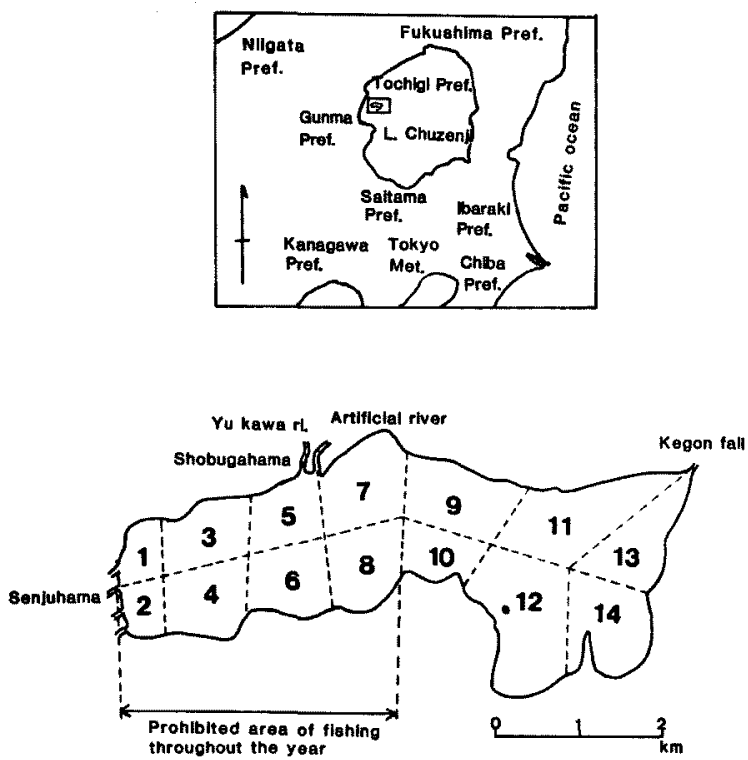

Fig. 1. Location of Lake Chuzenji zod fishing plots set up for the experimental fishing. Fishing plots 1 to 8 are prohibited area of fishing throughout the year and other plots are open to fishermen and general leisure fishing from late in April to mid-September.

their scaled body length, body weight, sex and gonad stage in terms of each fishermen and each fishing plot.

\section{Results and Discussion}

\section{Results of Fishing}

Results of fishing in each day of the examination are shown in Table 2.

Because hime salmon was the target, a gear for use in hime salmon fishing was used. As the results, $85.5 \%$ (2948 fishes) of the total catch (3447 fishes) was identified as hime salmon. As to the other fish species, 5.7\% (195 fishes) of the total catch was identified as hon masu (a hybrid of biwa trout Oncorhyncus rhodurus who inhabits Lake Chuzenji and masu salmon $O$. masou) and $5.2 \%$ (178 fishes) was brown trout Salmo trutta. However, in May and July in 1985 and July and September in 1986, the fishing ratio of hon masu or brown trout increased, relatively.

In addition to species shown in Table 2 , it was confirmed that 11 species inhabit, char Salvelinus pluvius, brook char $S$. fontindlis, and other else.

The number of hime salmon individuals fished up in each examination months is shown in Table 3 , in terms of the sex. In 1985 , the number of catch showed a tendency to decrease as the months of the examination advanced. In and after September of 1986 , on the contrary, the number of catch showed a tendency to increase, and 848 fishes of hime salmon were fished up in March of 1987 which were equivalent to $28.8 \%$ of the total catch through the 13 times of examination. Because the examination was not continued further, it was not possible to elucidate if such a phenomenon was transitory or reflecting changes in the amount of stocks.

\section{Sex Ratio}

The sex ratio was calculated by ratio of number of male to total fishes. Mean sex ratio through the total examination was 0.53 , that is, the number of males were slightly higher than that of females. According to a report on a similar examination at Lake Shikotsu, males were dominant in early and late period of spawning migration, but female dominated in middle period. ${ }^{\theta)}$ Sex ratio in each fishing plot in each examination month is shown in Fig. 2.

Stocking of hime salmon juveniles into Lake Chuzenji has been performed mostly at an artificial river of Shobugahama beach between fishing plots 5 and 7, except for occasional stocking at fishing plots 1 and 2 near Senjugahama beach. ${ }^{\text {s) }}$ Therefore, it can be concluded that most of the 
Table 2. Results of experimental fishing performed 13 times from March 1985 to March 1987

\begin{tabular}{|c|c|c|c|c|c|c|c|c|c|c|}
\hline \multirow{2}{*}{ Year } & \multirow{2}{*}{\multicolumn{2}{|c|}{ Date }} & \multirow{2}{*}{$\begin{array}{l}\text { No. of } \\
\text { total } \\
\text { catches }\end{array}$} & \multicolumn{7}{|c|}{ Species } \\
\hline & & & & $\begin{array}{c}\text { Hime } \\
\text { salmon }\end{array}$ & $\begin{array}{l}\text { Hon } \\
\text { masu }\end{array}$ & $\begin{array}{c}\text { Brook } \\
\text { trout }\end{array}$ & $\begin{array}{c}\text { Coho } \\
\text { salmon }\end{array}$ & $\begin{array}{c}\text { Rainbow } \\
\text { trout }\end{array}$ & $\begin{array}{c}\text { Brown } \\
\text { trout }\end{array}$ & Others \\
\hline \multirow{5}{*}{1985} & Mar. & $\begin{array}{r}27 \\
28 \\
\text { Total }\end{array}$ & $\begin{array}{l}184 \\
181 \\
365\end{array}$ & $\begin{array}{l}171 \\
174 \\
345\end{array}$ & $\begin{array}{l}6 \\
1 \\
7\end{array}$ & $\begin{array}{l}2 \\
1 \\
3\end{array}$ & & & $\begin{array}{l}1 \\
1 \\
2\end{array}$ & $\begin{array}{l}4 \\
4 \\
8\end{array}$ \\
\hline & May & $\begin{array}{r}27 \\
28 \\
\text { Total }\end{array}$ & $\begin{array}{l}204 \\
125 \\
329\end{array}$ & $\begin{array}{r}153 \\
81 \\
234\end{array}$ & $\begin{array}{r}18 \\
6 \\
24\end{array}$ & & & $\begin{array}{l}4 \\
4 \\
8\end{array}$ & $\begin{array}{l}29 \\
34 \\
63\end{array}$ & \\
\hline & July & $\begin{array}{r}22 \\
23 \\
\text { Total }\end{array}$ & $\begin{array}{l}110 \\
102 \\
212\end{array}$ & $\begin{array}{r}76 \\
63 \\
139\end{array}$ & $\begin{array}{r}8 \\
12 \\
20\end{array}$ & $\begin{array}{l}1 \\
2 \\
3\end{array}$ & & $\begin{array}{l}1 \\
1\end{array}$ & $\begin{array}{l}23 \\
21 \\
44\end{array}$ & $\begin{array}{l}1 \\
4 \\
5\end{array}$ \\
\hline & Sep. & & $\begin{array}{r}74 \\
76 \\
150\end{array}$ & $\begin{array}{r}71 \\
70 \\
141\end{array}$ & $\begin{array}{l}2 \\
2\end{array}$ & & $\begin{array}{l}1 \\
1\end{array}$ & & $\begin{array}{l}1 \\
4 \\
5\end{array}$ & $\begin{array}{l}1 \\
1\end{array}$ \\
\hline & Nov. & 28 & 58 & 31 & 10 & & 1 & 16 & & \\
\hline \multirow{6}{*}{1986} & Jan. & $\begin{array}{r}27 \\
28 \\
\text { Total }\end{array}$ & $\begin{array}{l}15 \\
12 \\
27\end{array}$ & $\begin{array}{r}3 \\
11 \\
14\end{array}$ & & 2 & $\begin{array}{l}2 \\
1 \\
3\end{array}$ & $\begin{array}{l}10 \\
10\end{array}$ & & \\
\hline & Mar. & $\begin{array}{r}26 \\
27 \\
\text { Total }\end{array}$ & $\begin{array}{l}110 \\
113 \\
223\end{array}$ & $\begin{array}{l}102 \\
100 \\
202\end{array}$ & $\begin{array}{l}1 \\
1\end{array}$ & 5 & $\begin{array}{l}2 \\
5 \\
7\end{array}$ & $\begin{array}{r}5 \\
7 \\
12\end{array}$ & $\begin{array}{l}1 \\
1\end{array}$ & \\
\hline & May & $\begin{array}{r}27 \\
28 \\
\text { Total }\end{array}$ & $\begin{array}{l}31 \\
27 \\
58\end{array}$ & $\begin{array}{r}15 \\
8 \\
23\end{array}$ & $\begin{array}{l}6 \\
6\end{array}$ & & & $\begin{array}{r}6 \\
4 \\
10\end{array}$ & $\begin{array}{r}10 \\
9 \\
19\end{array}$ & \\
\hline & July & $\begin{array}{r}23 \\
24 \\
\text { Total }\end{array}$ & $\begin{array}{l}158 \\
169 \\
327\end{array}$ & $\begin{array}{l}126 \\
135 \\
261\end{array}$ & $\begin{array}{r}8 \\
12 \\
20\end{array}$ & & & $\begin{array}{r}5 \\
7 \\
12\end{array}$ & $\begin{array}{l}19 \\
14 \\
33\end{array}$ & $\begin{array}{l}1 \\
1\end{array}$ \\
\hline & Sep. & $\begin{array}{r}24 \\
25 \\
\text { Total }\end{array}$ & $\begin{array}{l}129 \\
122 \\
251\end{array}$ & $\begin{array}{r}81 \\
93 \\
174\end{array}$ & $\begin{array}{l}38 \\
24 \\
62\end{array}$ & & & $\begin{array}{l}4 \\
2 \\
6\end{array}$ & $\begin{array}{l}6 \\
2 \\
8\end{array}$ & $\begin{array}{l}1 \\
1\end{array}$ \\
\hline & Nov. & $\begin{array}{r}27 \\
28 \\
\text { Total } \\
\end{array}$ & $\begin{array}{l}136 \\
154 \\
290 \\
\end{array}$ & $\begin{array}{l}121 \\
141 \\
262 \\
\end{array}$ & $\begin{array}{r}13 \\
8 \\
21 \\
\end{array}$ & & & $\begin{array}{l}1 \\
4 \\
5 \\
\end{array}$ & $\begin{array}{l}1 \\
1 \\
2 \\
\end{array}$ & \\
\hline \multirow[t]{2}{*}{1987} & Jan. & $\begin{array}{r}23 \\
24 \\
\text { Total }\end{array}$ & $\begin{array}{r}70 \\
216 \\
286\end{array}$ & $\begin{array}{r}64 \\
210 \\
274\end{array}$ & $\begin{array}{l}3 \\
3 \\
6\end{array}$ & $\begin{array}{l}1 \\
2 \\
3\end{array}$ & & $\begin{array}{l}2 \\
1 \\
3\end{array}$ & & \\
\hline & Mar. & $\begin{array}{r}23 \\
24 \\
\text { Total } \\
\end{array}$ & $\begin{array}{r}491 \\
379 \\
870 \\
\end{array}$ & $\begin{array}{r}474 \\
374 \\
848 \\
\end{array}$ & $\begin{array}{r}14 \\
2 \\
16 \\
\end{array}$ & $\begin{array}{r}3 \\
3 \\
\end{array}$ & & $\begin{array}{l}2 \\
2 \\
\end{array}$ & $\begin{array}{l}1 \\
1 \\
\end{array}$ & \\
\hline \multicolumn{3}{|c|}{ Ground Total } & 3446 & 2948 & 159 & 12 & 12 & 85 & 178 & 16 \\
\hline
\end{tabular}

Table 3. Monthly changes of the catch in number of hime salmon in term of the sex

\begin{tabular}{rlrrrr}
\hline Year & Month & Male & Female & Total & Sex ratio \\
\hline \multirow{4}{*}{1985} & Mar. & 157 & 188 & 345 & 0.46 \\
& May & 85 & 149 & 234 & 0.36 \\
& July & 73 & 66 & 139 & 0.53 \\
& Sep. & 75 & 66 & 141 & 0.53 \\
& Nov. & 14 & 17 & 31 & 0.45 \\
\hline \multirow{4}{*}{1986} & Jan. & 5 & 9 & 14 & 0.36 \\
& Mar. & 105 & 97 & 202 & 0.52 \\
& May & 10 & 13 & 23 & 0.44 \\
& July & 153 & 108 & 261 & 0.59 \\
& Sep. & 101 & 73 & 174 & 0.58 \\
& Nov. & 144 & 118 & 262 & 0.55 \\
\hline \multirow{2}{*}{1987} & Jan. & 160 & 114 & 274 & 0.58 \\
& Mar. & 471 & 377 & 848 & 0.56 \\
\hline
\end{tabular}


Jan.
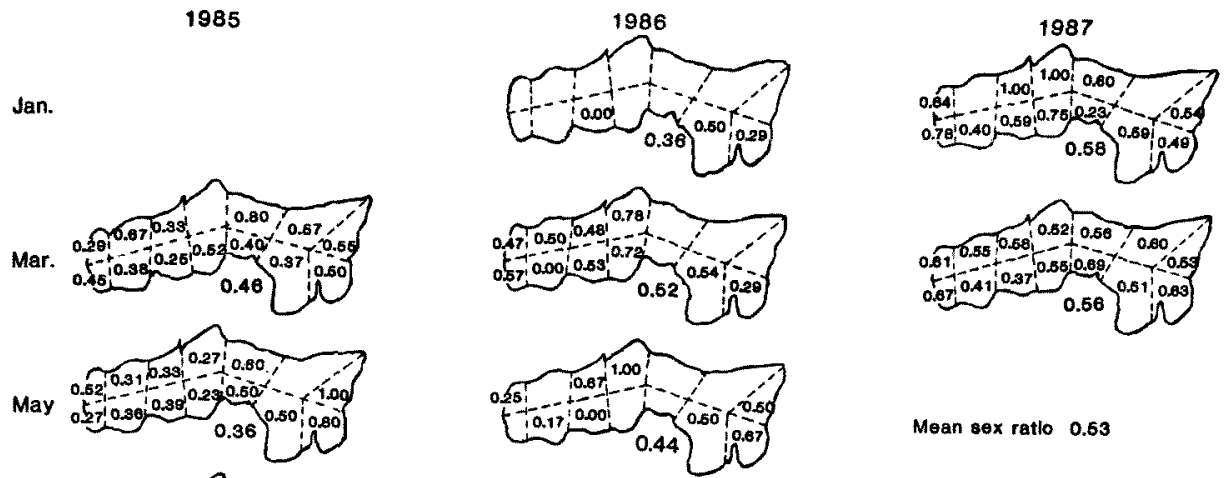

Mean sex ratlo 0.63
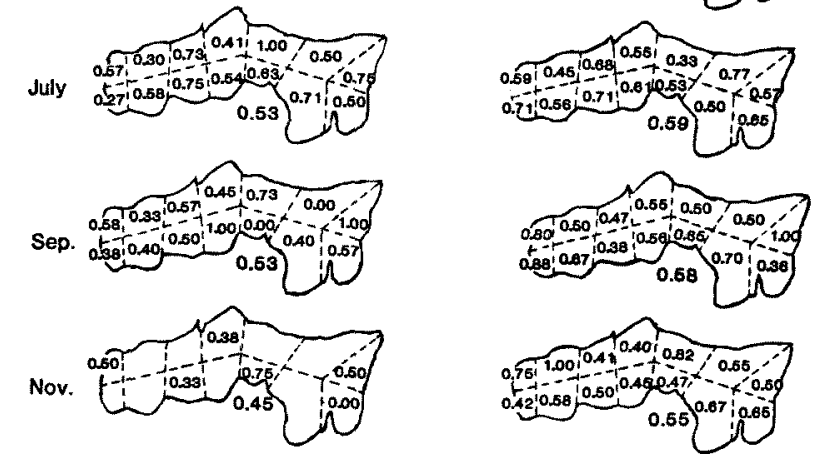

Fig. 2. Difference in the sex ratio of hime salmon among fishing plots. Figures noted outside the column indicate mean sex ratio of whole fishing plots in corresponding month.

spawning groups are concentrated toward Shobugahama beach because of the homing habit in September. When mean sex ratios at these two fishing plots in September and November were compared, the mean sex ratio was almost the same (0.51) in September of 1985 and 1986, but females were dominant in November with the sex ratio of 0.38 in 1985 and 0.41 in 1986, showing a tendency that the number of females was the same as males in the early period of spawning but higher in late spawning period.

Such a tendency, however, was not able to be concluded because of problems that the results were not analyzed in terms of age, namely, difference between spawning parent group and nonspawning parent group, and that no examination was performed in October when spawning is most active. These problems were remained as future subjects to be solved.

\section{Population Density}

Since each examination was performed for two days excluding November in 1985 and, despite the one man/one plot principle, two to three fishermen were posted at one fishing plot or a person in charge of a plot worked also at other plots in same cases, the population density was calculated at each fishing plot as the catch in number per day per man (CPUE). Results of the calculation are shown in Fig. 3.

The highest CPUE (44.5 fishes/day/man) throughout the whole examination was observed at fishing plot 9 in March of 1987, followed by 44.0 fishes/day/man at plot 1 in March of 1986. With regard to the annual changes in mean CPUE, a decreasing tendency with the advance of months was observed in 1985. In 1986, the mean CPUE decreased with the advance of months similar to the case of 1985, excluding January and May when catch in number was remarkably small compared to the other months.

The value, however, was fairly high in November of 1986 and January and March of the next year. Regarding the fishing plot, high CPUE values were observed at fishing plots toward the rear of the during the closed season from September to the next April. In May and July when fishing was open to the public, CPUE values were high at fishing plots arranged in the prohibited area of fishing throughout the year. 

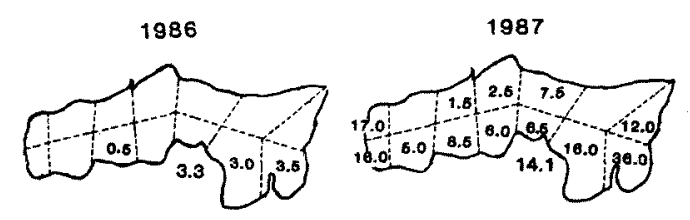

Jan.
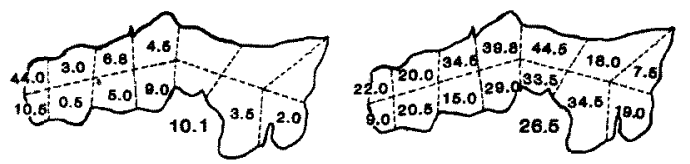

Mar.
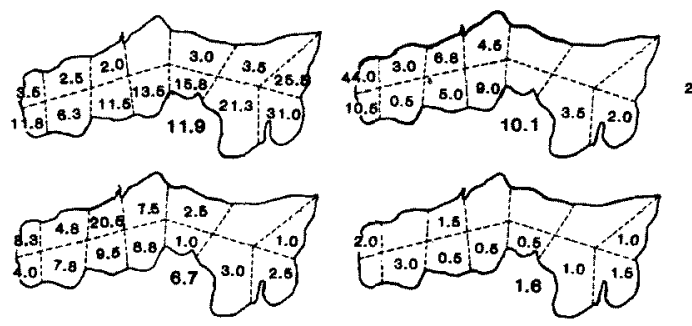

July
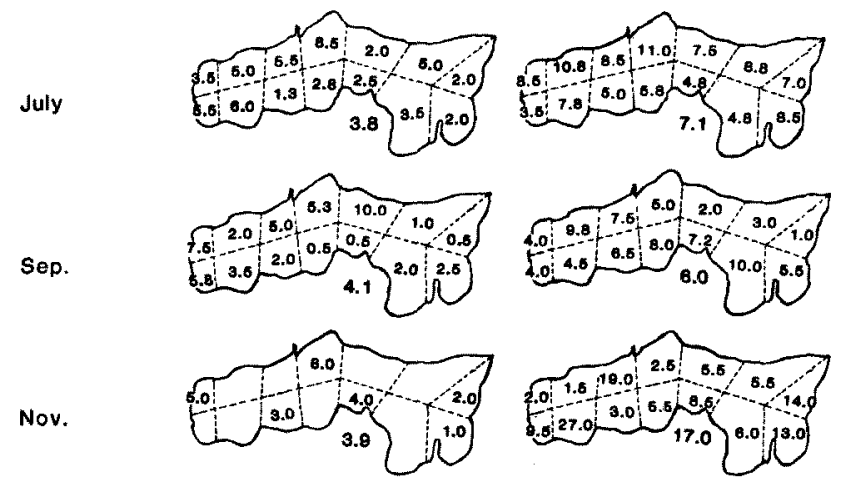

Fig. 3. Distribution of CPUE of hime salmon in terms of fishing plots. Figures noted outside the column indicate mean CPUE value of whole fishing plots in corresponding month.

Seasonal Changes in the Body Length Distribution

Since a difference in the body length between males and females of fished up hime salmon was hardly observed, body length distribution was divided at $1 \mathrm{~cm}$ intervals independent of sex. The results are shown in Fig. 4.

In 1985, the distribution was unimodal with the peak at around $25 \mathrm{~cm}$ class in March and May, but the distribution became biomodal in July with the peaks at around $20 \mathrm{~cm}$ and $27 \mathrm{~cm}$ classes, showing an increase in the number of small-sized fishes. In September, the distribution of the body length became more broad (13 $\mathrm{cm}$ to $34 \mathrm{~cm}$ classes) with no remarkable mode. In November, though the catch number was small because the examination was performed only for one day, the body length distribution became relatively narrow $(20 \mathrm{~cm}$ to $27 \mathrm{~cm})$ because fishes with a body length of $28 \mathrm{~cm}$ or longer were not caught.

In this case, it seems that the fishes with a body length of $28 \mathrm{~cm}$ and longer, disappeared from the lake but ascended a stream to join reproduc- tion activities, because the ascended a stream of spawning schools of hime salmon is generally from September to October and, though the body length of reproduction-joining group varies depending on each lake and year, ${ }^{7-8)}$ mean body length of main spawning groups which have been collected during the period from 1971 to 1987 at Lake Chuzenji by beach seine or fish traps at artificial stream was $27 \mathrm{~cm}$ to $28 \mathrm{~cm}$.)

In 1986, a mode of distribution was observed with a peak at $25 \mathrm{~cm}$ to $26 \mathrm{~cm}$ classes during the period of from January to May, though the catch in number was small in January and May. In July, the mode was slightly different from that in the same season of the previous year. That is, the main group in July of 1986 was small-sized fishes with a peak at around $19 \mathrm{~cm}$ class and with no significant mode of large-sized fishes because, mainly, of the small catch in number of the latter, while the distribution of the body length in the same season of the previous year was bimodal with peaks at around the $20 \mathrm{~cm}$ and $27 \mathrm{~cm}$ classes.

After July, the catch in number of large-sized 


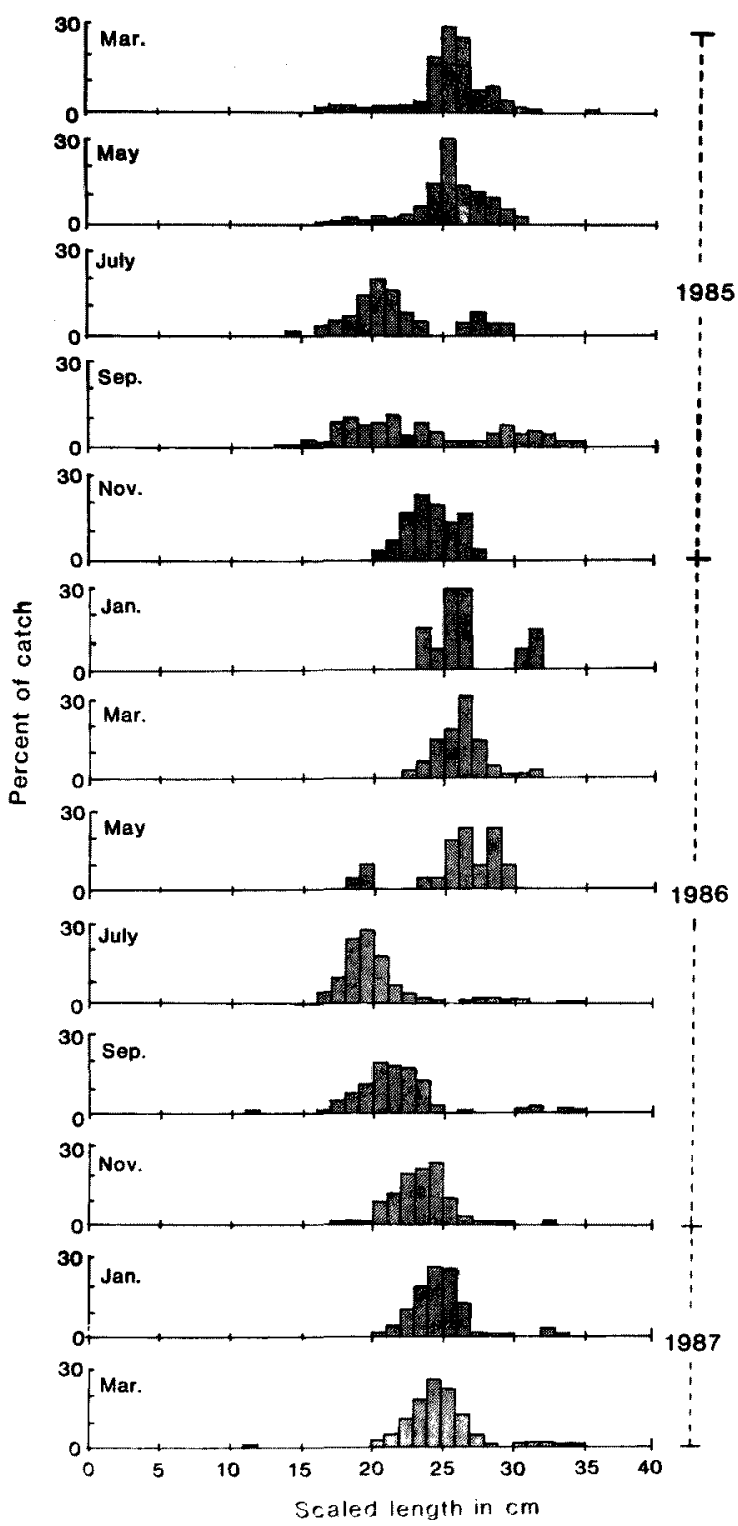

Fig. 4. Change in the body length distribution in each examination month.

fishes was not high, but the group showing a mode of body length distribution shifted gradually toward large-sized ones as if growing fishes with the advance of months have been fished up. In addition, a small number of large-sized fishes with a body length of $28 \mathrm{~cm}$ or longer were fished up in and after November of 1986, whereas such a large fish was not fished up in November of the pervious year.

\section{Recruitment Time}

Judging from seasonal changes of body length distribution, fishes of 24 to $27 \mathrm{~cm}$ class were dominant from January to May and fishes with less than $20 \mathrm{~cm}$ appeared from July. The fished individuals were therefore classified into four groups according to the body length (less than $20 \mathrm{~cm}, 20$ to $23 \mathrm{~cm}, 24$ to $27 \mathrm{~cm}$ and more than $28 \mathrm{~cm}$ ) and the frequency of seasonal appearance 
1985
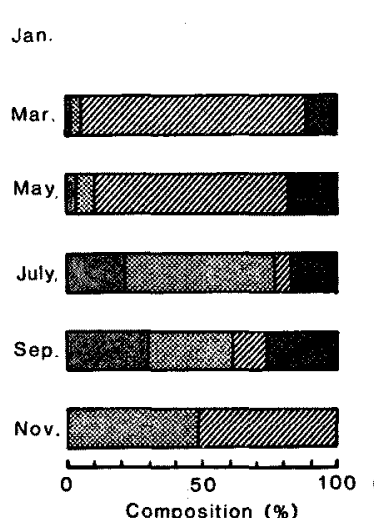

1986
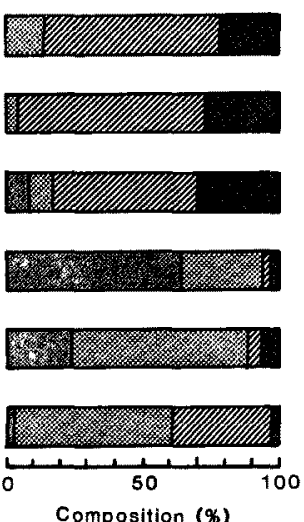

1987

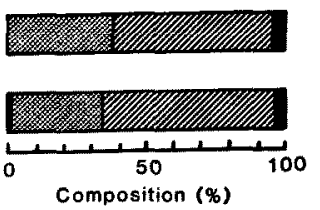

Less than $20 \mathrm{~cm}$

褟 $20 \sim 23.9 \mathrm{~cm}$

狗 $24 \backsim 27.8 \mathrm{~cm}$

More than $28 \mathrm{~cm}$

Fig. 5. Composition of body length groups in each examination month. Each groups can be regarded as follows.

Less than $20 \mathrm{~cm}$ : Newly recruited group at the time.

20 to $23.9 \mathrm{~cm}$ : Group just after the recruitment.

24 to $27.9 \mathrm{~cm}$ : Adult migration group.

More than $28 \mathrm{~cm}$ : Pre-spawning group.

of each body length group was examined. The results are as shown in Fig. 5. In this case, fishes with the body length of less than $20 \mathrm{~cm}$ were regarded as a newly recruited group at the time, those with the body length of 20 to $23 \mathrm{~cm}$ were regarded as a group not so long after recruitment as resources, namely a group just after recruitment, those with $24 \mathrm{~cm}$ to $27 \mathrm{~cm}$ body lengths were regarded as an adult migration group and those with more than $28 \mathrm{~cm}$ were regarded as a prespawning group.

On the basis of such an assumption, a process can be supposed that frequency of the appearance of relatively small fishes of the newly recruited group and the group just after recruitment increases from May through September and, in November, fishes that had completed the recruitment and grown up became frequent and, instead, large-sized fishes with the body length of $28 \mathrm{~cm}$ or longer start to ascend a stream for spawning and disappear from the fishing ground.

As described above, large sized fishes with a body length of $28 \mathrm{~cm}$ or longer were fished up even in and after November of 1986 . One reason for this may be explained as result of the frequent appearance of smaller fishes than the previous year due to over density or the frequent appearance of fishes who could not reach sexual maturation despite their body sizes due to insufficient supply of feed compared to the previous year, taking into consideration that hime salmon fishes were examined at the time of the liberation of 2.7 to 3.6 million juveniles and that a relation of the amount of feed to the rate of group maturity has been reported. ${ }^{10)}$

Because frequency of the appearance of small fishes with the body length of $23 \mathrm{~cm}$ or below (that is, the newly recruited group and the group of just after recruitment) increased during the period of from May through September, the ratio of each body length group to the total catch in number was calculated in term of each fishing plot in May, July and September. The results are shown in Fig. 6.

Though an absolute conclusion was not obtained because of the presence of fishing plots with a small catch in number, the newly recruited group with the body length of less than $20 \mathrm{~cm}$ seems to start to appear in May at fishing plots centering around the North-west side area of the lake and is distributed whole area of the lake in July.

In addition, fishes whose body lengths have already reached 20 to $23 \mathrm{~cm}$ in spring season of the year may probably be the ones who have completed the recruitment in autumn of the previous year and passed the subsequent winter. It seems that such fishes start to appear in May at fishing plots 1 to 4 and then are distributed in the whole area of the lake by July.

With regard to the recruitment time, it can be 

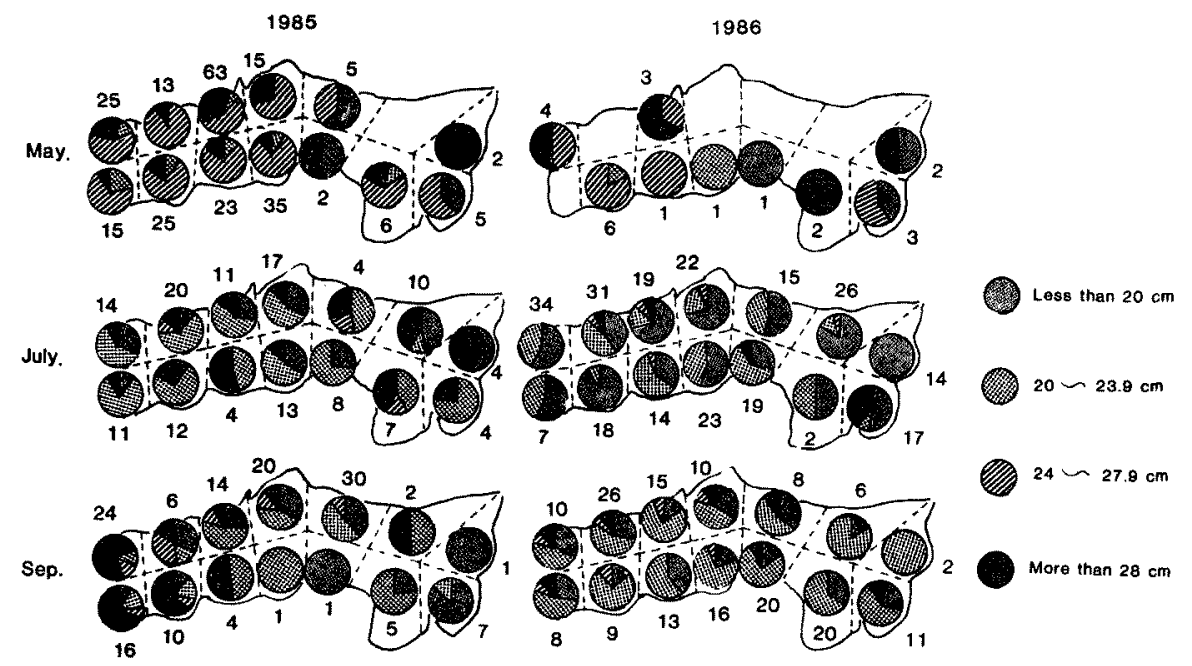

Fig. 6. Frequency of each body length group fished up at each fishing plot during the active recruitment season.

Figures noted outside the column indicate catch in number at corresponding fishing plot.

assumed that the recruitment starts in May when fishes grow into certain sizes with the main group having 18 to $19 \mathrm{~cm}$ of the body length, reaches its maximum in July and is completed in September when large-sized spawning fishes ascend a stream and disappear from the lake thus filling the space left after the ascending. Provided that the recruitment starts at a specific fishing plot, it is necessary to further examine the ecological meanign of the starting plot.

\section{Acknowledgments}

We wish to express our sincere gratitude to the ex-director Isao Okachi and the former director Tamezo Maruyama of Nikko Branch of National Research Institute of Aquaculture, Fisheries Agency, for their guidance and also to the staff and member of Lake Chuzenji Fisheries Cooperative Association for their close cooperation with the experimental fishing examination.

\section{References}

1) J. S. Nelson: J. Fish. Res. Bd. Canada, 25, 409414 (1968).

2) R. Ade: in "The trout and salmon handbook", Christober Helm, London, 1989, p. 36.

3) Y. Handa: Jap. J. Limnol., 8, 505-512 (1938).

4) K. Tanaka: Tansuiken shiryo, B. No. 10, 17-28 (1967).

5) N. Okumoto: Yoshokuken shiryo, No. 6, 4965 (1989).

6) T. Tokui: Sci. Rep. Hokkaido Salmon hatchery, 16, 127-133 (1961).

7) T. Kurohagi: Sci. Rep. Hokkaido Salmon hatchery, 18, 91-111 (1963).

8) T. Kurohagi: Sci. Rep. Hokkaido Salmon hatchery, 19, 61-74 (1964).

9) T. Kurohagi: Sci. Rep. Hokkaido Salmon hatchery, 20, 119-132 (1965).

10) T. Kato, Y. Fukuda, and Y. Sakamoto: Bull. Freshwater Fish. Res. Lab., 14, 97-105 (1965). 